Stanisław Bożyk

\title{
KADENCJA PARLAMENTU WE WSPÓŁCZESNYCH SYSTEMACH KONSTYTUCYJNYCH
}

1. Problematyka wyznaczenia czasu (okresu) sprawowania funkcji przez wylaniane $\mathrm{z}$ woli suwerena gremia parlamentarne zaliczana jest tradycyjnie do najistotniejszych zagadnień w prawie konstytucyjnym ${ }^{1}$. Powoływanie składu parlamentu w drodze wyborów powszechnych i bezpośrednich na konstytucyjnie określoną kadencję ${ }^{2}$ stanowi bowiem od dawna jeden $z$ uniwersalnych standardów oceny demokratyzmu praktycznie każdego systemu ustrojowego. Kadencyjność parlamentu uznawana jest przy tym w doktrynie prawa konstytucyjnego za konieczny element przedstawicielskiego charakteru tego organu, gdyż ,tylko okresowa oraz poddana sztywnym procedurom i terminom odnawialność składu parlamentu (w powiązaniu z demokratycznym prawem wyborczym) może mu nadawać charakter organu rzeczywiście reprezentatywnego"3. Przyjęcie zasady kadencyjności parlamentu ${ }^{4}$ spełnia zarazem istotną funkcję gwarancyjną. W sytuacji, kiedy obowiązujące przepisy konstytucyjne nie przewidują możliwości skrócenia kadencji parlamentu (bądź też jednej z jego izb) w ściśle określonych wypadkach oraz z zastosowaniem określonej procedury, domniemanie przemawia bowiem za sztywną kadencją, a więc za wyłączeniem jakichkolwiek możliwości jej skrócenia ${ }^{5}$.

Analiza obowiązujących ustaw zasadniczych pozwala na stwierdzenie, że przyjęte w ich treści regulacje prawnoustrojowe odnoszące się do problematyki kadencji parlamentu są w istotny sposób zróżnicowane w poszczególnych systemach konsty-

1 Por. H. Hofmann, H. Dreier, Repräsentation, Mehrheitsprinzip und Minderheitenschutz, (w:) Parlamentrecht und Parlamentspraxis in der Bundesrepublik Deutschland, red. H-P. Schneider, W. Zeh, Berlin 1989, s. 165 i nast.

2 Kadencja organu państwowego określana jest w doktrynie jako czas trwania pełnomocnictw tego organu, czyli okres, na jaki został on wybrany. Por. m.in. F. Siemieński, Prawo konstytucyjne, Warszawa 1978, s. 263.

3 L. Garlicki, Polskie prawo konstytucyjne. Zarys wykładu, Warszawa 2007, s. 196.

$4 \quad$ Warto podkreślić, że treść zasady kadencyjności określona została m.in. w wyroku Trybunału Konstytucyjnego z dnia 26 maja 1998 r. (K.17/98). Trybunał stwierdził, że na zasadę kadencyjności składaja się trzy podstawowe elementy. Po pierwsze, „nakaz nadania pełnomocnictwom danego organu z góry oznaczonych ram czasowych. Po drugie, wymienione ramy czasowe nie moga przekroczyć rozsądnych granic. Po trzecie, kadencyjność oznacza nakaz ustanowienia regulacji prawnych, które zapewnią ukonstytuowanie się nowo wybranego organu tak, aby mógł on rozpocząć wykonywanie swoich funkcji bez nadmiernej zwłoki, po zakończeniu poprzedniej kadencji".

5 Por. Z. Czeszejko-Sochacki, Prawo parlamentarne w Polsce, Warszawa 1997, s. 130 i nast. 
tucyjnych. Dotyczy to zarówno czasu trwania kadencji parlamentów, jak też zasad oznaczania początku i końca kadencji oraz możliwości jej skrócenia lub przedłużenia. Poza tym w praktyce ustrojowej niektórych państw znajdują zastosowanie całkowicie odrębne zasady liczenia kadencji obu izb w parlamentach dwuizbowych.

2. Konstytucyjne wyznaczenie ram czasowych kadencji parlamentu ma w każdej sytuacji określone znaczenie. Gdy kadencja najwyższego organu przedstawicielskiego jest krótka, to deputowani są bardziej związani ze swoim elektoratem, gdyż częste wybory parlamentarne gwarantują wierne odzwierciedlenie w jego składzie dominujących w danym momencie orientacji politycznych w społeczeństwie. Parlamentarzyści są jednak wtedy mniej aktywni, ponieważ koncentrują się przede wszystkim na zapewnieniu sobie reelekcji w nadchodzących wyborach. W dodatku ,spora część nowo wybranych deputowanych potrzebuje czasu, aby wdrożyć się do pracy parlamentarnej i gdy już to uczynią, kadencja się kończy"6. Z kolei zbyt długie kadencje parlamentu powodują zwykle ograniczenie wpływu elektoratu na postawy reprezentantów, co w konsekwencji stwarza deputowanym większe możliwości prowadzenia działań bardziej niezależnych oraz zgodnych z ich własnym sumieniem i zainteresowaniami. Takie kadencje sprzyjają jednak zawsze stabilności parlamentu, gdyż stwarzają mu znacznie większe możliwości planowania i wykonywania zadań w dłuższej perspektywie czasowej, a tym samym służą bardziej efektywnej partycypacji tego organu władzy ustawodawczej w realizacji zasadniczych kierunków polityki państwa?

W historii znajdowały niejednokrotnie zastosowanie zarówno niezwykle krótkie kadencje parlamentów ${ }^{8}$, jak też wyjątkowo długie okresy kadencji tych organów9 We współczesnych systemach ustrojowych nie występują już tak znaczne dysproporcje w odniesieniu do ram czasowych kadencji najwyższych organów przedstawicielskich. Najczęściej przyjmowane są tak zwane ,uśrednione” długości kadencji, a więc kadencje czteroletnie oraz pięcioletnie. Pod tym względem wyróżniają się przede wszystkim parlamenty jednoizbowe, którym wyznacza się zawsze sztywno określone i mieszczące się $\mathrm{w}$ tych granicach długości kadencji.

Ujednolicone kadencje, ograniczone konstytucyjnie do czterech lat, posiadają obecnie zwłaszcza parlamenty jednoizbowe we wszystkich państwach skandynawskich. Konstytucja Danii z 1953 r. w $§ 32$ ust. 1 przewiduje, że deputowani do Fol-

6 B. Banaszak, Porównawcze prawo konstytucyjne współczesnych państw demokratycznych, Kraków 2004, S. 440 .

$7 \quad$ Por. Z. Czeszejko-Sochacki, Prawo parlamentarne..., s. 133.

8 Wskazać tu należy zwłaszcza na rozwiązania przyjęte w konstytucji Rosji radzieckiej z 1918 r., przewidujące zaledwie trzymiesięczną kadencję najwyższego organu przedstawicielskiego.

$9 \quad$ Najbardziej charakterystycznym przykładem może być w tym wypadku kadencja parlamentów niektórych krajów niemieckich w XIX stuleciu, która wynosiła aż 12 lat. 
ketingu wybierani są na cztery lata ${ }^{10}$. Podobnie czyni przepis $\S 54$ konstytucji Norwegii z 1814 r., stanowiąc, że wybory do parlamentu (Stortingu) odbywają się co cztery lata ${ }^{11}$. Czteroletnią kadencję parlamentu ustala aktualnie także szwedzki Akt o Formie Rządu z 1974 r. ${ }^{12}$, ale należałoby tu jednak zaznaczyć, że w Szwecji w latach 1969-1994 kadencja parlamentu (Riksdagu) była dość nietypowa, bo wynosiła trzy lata. Konstytucja Islandii z 1944 r. przewiduje z kolei (art. 63), że "Althing składa się z 63 deputowanych wybieranych przez naród na cztery lata w głosowaniu tajnym opartym na zasadzie proporcjonalności"13. Jednoznacznie kadencji parlamentu nie określa jedynie konstytucja Finlandii z 1999 r., która w treści § 24 stwierdza, że kadencja Eduskunty ,rozpoczyna się wraz z ogłoszeniem wyników wyborów powszechnych i trwa do następnych wyborów powszechnych"14. To sformułowanie konstytucji precyzuje jednak przepis $\S 3$ Aktu o Parlamencie, który przyjął zasadę odbywania regularnych wyborów parlamentarnych co cztery lata ${ }^{15}$. Tym samym w drodze ustawodawczej ustanowiona została czteroletnia kadencja parlamentu Finlandii.

Kolejną grupą państw, w których funkcjonują parlamenty jednoizbowe z konstytucyjnie określoną czteroletnią kadencją parlamentu, są niektóre państwa postkomunistyczne: Słowacja, Węgry i Bułgaria. Konstytucja Słowacji z 1992 r. w art. 73 ust. 2 przewiduje, że: "Rada Narodowa Republiki Słowackiej składa się ze 150 posłów, którzy są wybierani na cztery lata"16. Konstytucja Węgier z 1949 r. stanowi z kolei w $§ 20$ ust. 1, że: ,Wybory powszechne deputowanych do Zgromadzenia Krajowego zarządza się w miesiącu kwietniu lub maju roku czwartego od wyboru poprzedniego Zgromadzenia Krajowego"17. Podobnie problematykę kadencji parlamentu reguluje konstytucja Bułgarii z 1991 r., której przepis art. 64 ust. 1 stwierdza, iż: „Zgromadzenie Narodowe wybierane jest na okres czterech lat"18. Czteroletnia kadencja parlamentów jednoizbowych znalazła zastosowanie również w trzech republikach nadbałtyckich (Litwa, Łotwa, Estonia) oraz na Ukrainie.

W pozostałych państwach europejskich parlamenty jednoizbowe ukształtowane zostały jeszcze tylko w Grecji, Portugalii oraz Luksemburgu. Zarówno grecka Izba Deputowanych, jak też portugalskie Zgromadzenie Republiki wybierane są w wyborach powszechnych i bezpośrednich na czteroletnią kadencję. Wyjątkiem jest tu parlament Wielkiego Księstwa Luksemburga, gdzie licząca 60 parlamentarzystów Izba Deputowanych funkcjonuje w ramach pięcioletniej kadencji. Przesądza o tym

Konstytucja Królestwa Danii, tłumaczenie i wstęp M. Grzybowski, Warszawa 2002, s. 48.

Konstytucja Królestwa Norwegii, tłumaczenie i wstęp J. Osiński, Warszawa 1996, s. 36.

Konstytucja Królestwa Szwecji, wstęp M. Grzybowski, Warszawa 2000, s. 34.

Konstytucja Republiki Islandii, tłumaczenie i wstęp J. Osiński, Warszawa 2009, s. 43.

Konstytucja Republiki Finlandii, tłumaczenie i wstęp J. Osiński, Warszawa 2003, s. 72.

Por. M. Grzybowski, Eduskunta. Parlament Finlandii, Warszawa 2001, s. 29.

Konstytucja Republiki Słowackiej, tłumaczenie i wstęp K. Skotnicki, Warszawa 2003, s. 65.

Konstytucja Republiki Węgierskiej, wstęp W. Brodziński, Warszawa 2002, s. 41.

Konstytucja Republiki Bułgarii uchwalona 12 lipca 1991 r., pod red. R. Chruściaka, Warszawa 1993, s. 23. 
przepis art. 56 konstytucji z 1868 r., stanowiący, że: „Deputowani są wybierani na pięć lat"19. Jest to obecnie jedyny jednoizbowy parlament w Europie, który wybierany jest na pięcioletnią kadencję.

Czteroletnia kadencja znalazła także powszechne wykorzystanie prawie we wszystkich jednoizbowych parlamentach w państwach pozaeuropejskich ${ }^{20}$. Do nielicznych wyjątków w tym zakresie zaliczyć należy jednoizbowe parlamenty w Chińskiej Republice Ludowej oraz w Nowej Zelandii. Liczące zwykle prawie 3000 deputowanych Ogólnochińskie Zgromadzenie Przedstawicieli Ludowych wybierane jest, co do zasady, na pięcioletnią kadencję ${ }^{21}$. Z kolei Izba Reprezentantów Nowej Zelandii powoływana jest w wyborach na zdecydowanie krótszą kadencję, która wynosi jedynie trzy lata ${ }^{22}$.

3. Bardziej zróżnicowane rozwiązania prawnoustrojowe w odniesieniu do czasu trwania kadencji przyjęte zostały w tych państwach, w których funkcjonują parlamenty dwuizbowe. Biorąc pod uwagę istniejące różnice lub podobieństwa między izbami parlamentu w zakresie określania długości ich kadencji, możemy wyodrębnić cztery zasadnicze rozwiązania: 1) tylko jedna z izb parlamentu ma określoną kadencję, 2) kadencje obu izb liczone są na odmiennych zasadach, 3) zróżnicowane kadencje obu izb w państwach federacyjnych, 4) analogiczny czas trwania kadencji obu izb parlamentu.

Z sytuacją, kiedy tylko jedna z izb parlamentu posiada określoną kadencję, spotykamy się przede wszystkim w systemie parlamentarno-gabinetowym Wielkiej Brytanii. W tym modelu organem kadencyjnym i pochodzącym $\mathrm{z}$ wyborów powszechnych jest tylko izba pierwsza - Izba Gmin. Ustawa o parlamencie z $1911 \mathrm{r}$. przyjmuje w tym zakresie zasadę, że maksymalny czas trwania kadencji Izby Gmin wynosi pięć lat ${ }^{23}$. Skład drugiej izby parlamentu - Izby Lordów - kształtowany jest już w drodze pozawyborczej (tworzą ją lordowie dziedziczni, lordowie dożywotni, lordowie duchowni i lordowie prawa) i w konsekwencji nie ma też wyznaczonego okresu nawet częściowej zmiany składu osobowego tej izby. Analogiczne rozwiązanie znalazło zastosowanie w systemie konstytucyjnym Kanady. Tu również tylko Izba Gmin jest organem kadencyjnym, powoływanym w drodze wyborów

19 Konstytucja Wielkiego Księstwa Luksemburga, wstęp K. Wojtyczek, Warszawa 2006, s. 60.

20 W doktrynie podkreśla się niekiedy fakt, że aż $2 / 3$ państw posiada parlamenty jednoizbowe, natomiast tylko w $1 / 3$ współczesnych systemów ustrojowych funkcjonują parlamenty dwuizbowe. Por. A. Antoszewski, R. Herbut, Systemy polityczne współczesnego świata, Gdańsk 2001, s. 250.

21 Por. J. Rowiński, W. Jakóbiec, Parlament Chińskiej Republiki Ludowej, Warszawa 2008, s. 26.

22 Por. S. Bożyk, Izba Reprezentantów. Parlament Nowej Zelandii, Warszawa 2009, s. 27.

23 Trzeba przy tym podkreślić, że brytyjskiemu prawu konstytucyjnemu nie jest de facto znane pojęcie kadencji parlamentu jako określonego czasu trwania pełnomocnictw danych przedstawicielom do podejmowania decyzji w imieniu społeczeństwa. Zwoływanie nowej Izby Gmin, czyli zarządzenie powszechnych wyborów do tej izby, następuje bowiem zawsze w drodze proklamacji królewskiej, a nie poprzez podjęcie specjalnej uchwały o zakończeniu prac danej Izby Gmin. Por. P. Sarnecki, System konstytucyjny Zjednoczonego Królestwa Wielkiej Brytanii i Irlandii Północnej, Warszawa 2009, s. 28 i nast. 
powszechnych na pięcioletnią kadencję. Członkowie kanadyjskiego Senatu powoływani są natomiast przez Gubernatora Generalnego na wniosek premiera rządu federalnego. Senat nie ma wyznaczonej kadencji, bowiem senatorowie pełnią swoje mandaty do czasu rezygnacji, osiagnnięcia wieku emerytalnego (75 lat), utraty prawa zasiadania w tej izbie lub śmierci ${ }^{24}$.

Często spotykanym rozwiązaniem jest określanie długości kadencji obu izb parlamentu na zróżnicowanych zasadach. Wówczas jedna izba ma z reguły wyraźnie określoną kadencję, druga zaś, ze względu na odmienny sposób kształtowania jej składu, posiada kadencję o innej długości. Przykładem tego może być zwłaszcza system ustrojowy Stanów Zjednoczonych, gdzie członków drugiej izby parlamentu (Senatu) wybiera się na sześcioletnią kadencję, przy czym co dwa lata odbywają się wybory 1/3 ogólnej liczby senatorów. Izba Reprezentantów wybierana jest z kolei w całości na niespotykanie krótką, bo zaledwie dwuletnią kadencję $e^{25}$. Kolejnym państwem, gdzie również obie izby parlamentu mają kadencję o różnej długości, jest Francja. W systemie półprezydenckim V Republiki Francuskiej Zgromadzenie Narodowe (izba pierwsza) wybierane jest w wyborach powszechnych na pięcioletnią kadencję. Senatorowie wybierani są natomiast przez kolegium elektorów na dziewięć lat, z tym że co trzy lata skład Senatu jest odnawiany poprzez wybór 1/3 ogólnej liczby senatorów ${ }^{26}$. Kadencja obu izb parlamentu jest zróżnicowana także w systemie parlamentarnym Japonii. Przepis art. 45 konstytucji japońskiej z 1946 r. przewiduje dla izby pierwszej (Izby Reprezentantów) kadencję czteroletnią. Z kolei w art. 46 przyjęto zasadę, że członkowie drugiej izby (Izby Radców) są wybierani na sześć lat, ale co trzy lata musi być dokonywany wybór połowy składu tej izby ${ }^{27}$. Podobne rozwiązanie przyjęła także konstytucja Republiki Czeskiej z 1992 r. Kształtuje je przepis art. 16, który stanowi, że: „1. Izba Poselska liczy 200 posłów wybieranych na okres czterech lat. 2. Senat liczy 81 senatorów wybieranych na okres sześciu lat. Co dwa lata wybiera się 1/3 senatorów"28. Zaprezentowane tutaj rozwiązania nie są bynajmniej stosowane jedyne w tych czterech państwach. Kształtowanie zróżnicowanej długości kadencji obu izb parlamentu ma bowiem miejsce także w innych systemach rządów, jak chociażby w Australii, Brazylii, Holandii, Indiach oraz Meksyku.

Na odmienny sposób kształtowania długości kadencji obu izb parlamentu rzutuje zawsze federacyjna struktura państwa. Zwykle we wszystkich współczesnych federacjach pierwsza izba parlamentu ma wyraźnie określoną kadencję, natomiast

\footnotetext{
24 Por. M. Grzybowski, Szkice kanadyjskie (państwo-ustrój-obywatele), Kielce 2003, s. 109.

25 W ten sposób co 2 lata następuje wybór pełnego składu Izby Reprezentantów (435 deputowanych) oraz 1/3 składu Senatu. Por. A. Pułło, Ustroje państw współczesnych, Warszawa 2006, s. 118 i nast.

26 Por. E. Gdulewicz, Parlament Republiki Francuskiej, Warszawa 1993, s. 21.

27 Konstytucja Japonii, wstęp A. i L. Garliccy, Wrocław 1990, s. 41. Por też. K. Karolczak, System konstytucyjny Japonii, Warszawa 2008, s. 25 i nast.

28 Konstytucja Republiki Czeskiej, tłumaczenie i wstęp M. Kruk, Warszawa 1994, s. 38.
} 
poszczególni członkowie drugiej izby, stanowiącej parlamentarną reprezentację podmiotów federacji, mogą być powoływani na różną kadencję. Widoczne jest to szczególnie w parlamencie federalnym RFN. Posłowie do Bundestagu są tam wybierani w wyborach powszechnych i bezpośrednich na czteroletnią kadencję. Druga izba parlamentu (Bundesrat) nie jest dla odmiany organem kadencyjnym, bo jej skład osobowy kształtowany jest wyłącznie przez rządy krajowe. W konsekwencji okres piastowania mandatów w tej izbie przez reprezentantów określonych landów uzależniony jest od tego, jak długo w danym kraju związkowym władzę sprawuje ta sama koalicja rządowa ${ }^{29}$. Federalna struktura państwa ma też wpływ na kadencję parlamentu austriackiego. Kadencja izby pierwszej (Rady Narodowej) wynosi cztery lata, natomiast izba druga (Rada Federalna), reprezentująca 9 krajów wchodzących w skład Austrii, nie ma faktycznie wyodrębnionej kadencji. Do izby tej deputowani wybierani są bowiem przez parlamenty krajowe, które mają zróżnicowane kadencje i różne daty wyborów. W ten sposób poszczególni członkowie Rady Federalnej mogą piastować mandaty parlamentarne przez istotnie różniące się między sobą okresy kadencji. W praktyce każdorazowo kadencja członka Rady Federalnej zaczyna się z chwilą wyboru go do składu tej izby przez właściwy parlament krajowy, a kończy się wraz z upływem kadencji tego parlamentu ${ }^{30}$. Istotnie zróżnicowaną kadencję posiadają też obie izby parlamentu w kolejnej federacji europejskiej Szwajcarii. Kadencja izby pierwszej (Rady Narodowej) jest czteroletnia, natomiast okres trwania mandatu poszczególnych członków drugiej izby (Rady Kantonów) reguluje prawo kantonalne i dlatego izba ta nie ma jednolitej kadencji. Skład Rady Kantonów nie jest periodycznie w całości odnawiany $-\mathrm{z}$ wyjątkiem jej rozwiązania w następstwie całkowitej zmiany konstytucji, co jednak dotychczas nie miało miejsca $^{31}$. Obecnie we wszystkich kantonach praktykowany jest czteroletni okres trwania mandatu deputowanych reprezentujących kantony w składzie Rady Kantonów. Jego początek nie zawsze pokrywa się jednak z początkiem kadencji Rady Narodowej. W obowiązującym stanie prawnym połowa członków Rady Kantonów wybierana jest bowiem równocześnie z posłami do Rady Narodowej, druga połowa zaś podczas kadencji izby pierwszej parlamentu federalnego, ale nie zawsze w połowie tej kadencji.

Stosunkowo często spotykanym rozwiązaniem prawnoustrojowym jest też pokrywanie się długości kadencji obu izb parlamentu, które są zarazem wspólnie wyłaniane $\mathrm{w}$ drodze wyborów parlamentarnych. Jest to reguła praktykowana przede wszystkim w systemach ustrojowych Ameryki Łacińskiej, gdzie z wyjątkiem kil-

Zob. m.in. R. Herzog, Skład oraz zasady organizacji i funkcjonowania Bundesratu, (w:) Parlament Republiki Federalnej Niemiec, pod red. J. Isensee i P. Kirchhofa, Warszawa 1995, s. 222 i nast.

30 Zob. szerzej m.in. I. Kathrein, Rada Federalna, (w:) Parlament Republiki Austrii, pod red. H. Schambecka, Warszawa 1997, s. 103 i nast.

31 Por. J.F. Aubert, Parlament a Zgromadzenie Federalne, (w:) Parlament Szwajcarii, Warszawa 2000, s. 22-23;

P. Sarnecki, Zgromadzenie Federalne. Parlament Konfederacji Szwajcarskiej, Warszawa 2003, s. 10 i nast. 
ku państw (Argentyny, Brazylii, Chile, Meksyku) „dwuizbowe ciała przedstawicielskie wybierane są na całą kadencję w jednorazowym powszechnym akcie głosowania" ${ }^{32}$. Wśród państw Europy Zachodniej zasada powoływania obu izb parlamentu na identyczną kadencję znajduje zastosowanie m.in. w Hiszpanii oraz we Włoszech. Hiszpańska konstytucja z 1978 r. przewiduje w art. 68 ust. 2, że izba pierwsza (Kongres) jest wybierana na okres czterech, natomiast art. 69 ust. 6 wprowadza czteroletnią kadencję także w odniesieniu do izby drugiej (Senatu) ${ }^{33}$. Z kolei włoska ustawa zasadnicza z 1947 r. formułuje w art. 60 zasadę, że: „Izba Deputowanych i Senat Republiki są wybierane na pięć lat" ${ }^{\prime 34}$. Tym samym we Włoszech przyjęta została jednolita, pięcioletnia kadencja dla obu izb parlamentu ${ }^{35}$. Identyczna (czteroletnia) kadencja obu izb parlamentu wprowadzona została również przez niektóre państwa Europy Środkowej i Wschodniej: Rumunię, Rosję oraz Polskę.

4. Unormowania konstytucyjne we współczesnych systemach ustrojowych ograniczają się zazwyczaj jedynie do zakreślenia ram czasowych kadencji parlamentu, pomijając najczęściej określenie momentu, w którym kadencja ta się rozpoczyna, jak też wskazanie terminu jej zakończenia. W konsekwencji regulacja tej problematyki stanowi domenę ustawodawstwa zwykłego, choć w niektórych państwach także ustawy zasadnicze wyznaczają początek oraz koniec kadencji parlamentu.

W Stanach Zjednoczonych początek i koniec kadencji Kongresu nie został określony w pierwotnym tekście konstytucji federalnej z 1787 r. Uczyniła to dopiero, wprowadzona w życie w 1933 r., XX poprawka do obowiązującej konstytucji ${ }^{36}$. Poprawka ta przewiduje, że kadencja Izby Reprezentantów oraz wybranych w ostatnich wyborach senatorów (tworzących 1/3 ogólnej liczby członków Senatu) rozpoczyna się zawsze w południe 3 stycznia w roku nieparzystym. Upływa ona także w południe 3 stycznia po dwóch latach, a więc w kolejnym roku nieparzystym. Wówczas dobiega końca kadencja całej Izby Reprezentantów oraz tych senatorów, którzy przez ostatnich sześć lat zasiadali w składzie Senatu. Taka forma określenia początku i końca kadencji parlamentu nie jest znana w żadnym innym systemie ustrojowym.

Oryginalnym rozwiązaniem prawnoustrojowym jest konstytucyjne wyznaczenie początku i końca kadencji parlamentu w taki sposób, że koniec kadencji jest w każdym wypadku dniem przypadającym równo po upływie przewidzianego prawem okresu pełnomocnictw parlamentu od dnia wyborów parlamentarnych. Czyni tak art. 45 konstytucji Islandii, w którym przyjęto, że początek i koniec kadencji przy-

K. Complak, Parlament we współczesnej Ameryce Łacińskiej, Wrocław 1994, s. 37.

Konstytucja Hiszpanii, tłumaczenie i wstęp T. Mołdawa, Warszawa 2008, s. 52.

Konstytucja Republiki Włoskiej, tłumaczenie i wstęp Z. Witkowski, Warszawa 2004, s. 73.

Do 1963 r. obie izby parlamentu włoskiego wybierane były na jeszcze dłuższą, bo sześcioletnią kadencję. Por. J. Zakrzewska, Włochy. Zarys ustroju, Wrocław 1974, s. 86.

36 Konstytucja Stanów Zjednoczonych Ameryki, tłumaczenie i wstęp A. Pułło, Warszawa 2002, s. 62. 
pada „w tym samym dniu tygodnia w miesiącu, od którego liczy się początek kadencji" ${ }^{37}$. Podobnie początek kadencji parlamentu został określony w Izraelu przez art. 8 Ustawy Zasadniczej o Knesecie z 1958 r. Przewiduje on, że każdorazowo kadencja Knesetu ma być liczona od dnia przeprowadzenia wyborów do parlamentu. Z kolei upływ kadencji parlamentu Izraela następuje, zgodnie z art. 37 tej samej Ustawy Zasadniczej, dopiero w dniu poprzedzającym zebranie się na pierwsze posiedzenie po wyborach Knesetu nowej kadencji ${ }^{38}$.

W kilku ustawach zasadniczych wprowadzona została generalna zasada, że pierwszym dniem nowej kadencji parlamentu jest dzień zebrania się izby na pierwsze posiedzenie po wyborach parlamentarnych, natomiast ostatnim dniem kadencji jest dzień poprzedzający to właśnie posiedzenie. Takie rozwiązanie przewidziane zostało m.in. przez konstytucje Austrii, Portugalii oraz Rosji. Przepis art. 27 ust. 1 konstytucji Republiki Austriackiej stanowi w tej materii, że kadencja Rady Narodowej trwa cztery lata "licząc od dnia jej pierwszego zebrania się, zawsze jednak do dnia, w którym zbiera się nowo wybrana Rada" ${ }^{39}$. Analogicznie czyni obowiązująca konstytucja Portugalii w treści art. 153 ust. 1, który przewiduje, że kadencja parlamentu rozpoczyna się każdorazowo „,z dniem zebrania się Zgromadzenia Republiki na pierwsze posiedzenie po wyborach i kończy się z dniem pierwszego posiedzenia po kolejnych wyborach" ${ }^{40}$. Nieco inaczej zasada ta sformułowana została w ustawie zasadniczej Federacji Rosyjskiej. Deklaruje ją przepis art. 99 ust. 4, stanowiąc, że: "Z chwilą rozpoczęcia obrad Dumy Państwowej nowej kadencji wygasają pełnomocnictwa Dumy Państwowej poprzedniej kadencji”"41. Oznacza to, że również w Rosji kadencja parlamentu rozpoczyna się w dniu zebrania się izby na pierwsze po wyborach posiedzenie plenarne, upływa zaś w przededniu zebrania się nowego parlamentu po kolejnych wyborach parlamentarnych. Zastosowanie w tych trzech państwach takiej formy liczenia początku i końca kadencji parlamentu posiada przede wszystkim jedną zasadniczą zaletę, a mianowicie pozwala całkowicie wyeliminować przerwę międzykadencyjną.

5. Faktyczny czas trwania kadencji parlamentu jest niejednokrotnie znacznie krótszy aniżeli konstytucyjnie wyznaczone ramy czasowe kadencji, gdyż w wielu współczesnych systemach ustrojowych możliwe jest skrócenie jego kadencji w wyniku rozwiązania izby (izb) przez organ władzy wykonawczej lub też w drodze samorozwiązania parlamentu ${ }^{42}$. Sa jednak takie państwa, których konstytucje całkowicie wykluczają możliwość skrócenia kadencji czy to całego parlamentu, czy też

Konstytucja Republiki Islandii..., s. 46.

Por. S. Bożyk, Kneset. Parlament Izraela, Warszawa 2002, s. 29.

Federalna Ustawa Konstytucyjna Republiki Austrii, wstęp P. Czarny i B. Naleziński, Warszawa 2004, s. 68.

Konstytucja Republiki Portugalskiej, wstęp J. Miranda i P. Kownacki, Warszawa 2000, s. 106-107.

Konstytucja Federacji Rosyjskiej, wstęp A. Bosiacki, Warszawa 2000, s. 70.

Por. B. Banaszak, Porównawcze prawo konstytucyjne..., s. 440 i nast. 
jednej z jego izb (m.in. Norwegia i Szwajcaria). Rozwiązanie izby jest niedopuszczalne także tam, gdzie izba parlamentu nie jest organem kadencyjnym, tak jak ma to miejsce w przypadku brytyjskiej Izby Lordów czy kanadyjskiego Senatu. Poza tym instytucja rozwiązania parlamentu nie ma zastosowania w klasycznym systemie rządów prezydenckich, bowiem istotą tego modelu ustrojowego jest przede wszystkim maksymalne odseparowanie poszczególnych władz centralnych oraz przyjęcie zasady równowagi między nimi (zwłaszcza w relacjach między legislatywą a egzekutywą) $)^{43}$.

We współczesnych systemach konstytucyjnych prawo skrócenia kadencji parlamentu przysługuje najczęściej głowie państwa. Takie rozwiązanie prawnoustrojowe stosowane jest najdłużej w modelu brytyjskim, gdzie przy braku sztywnych ram czasowych kadencji tylko monarcha może podjąć decyzję o jej zakończeniu ${ }^{44}$. W praktyce ustrojowej Wielkiej Brytanii wręcz regułą stało się wcześniejsze rozwiązywanie Izby Gmin, które ma miejsce najczęściej wtedy, gdy partia rządząca uznaje dany moment za najdogodniejszy do wygrania wyborów. Choć formalnie decyzję o rozwiązaniu Izby Gmin podejmuje monarcha, to w rzeczywistości należy ona do premiera, a więc do partii dysponującej większością mandatów poselskich w tej izbie parlamentu. Na wzór brytyjski taka forma skrócenia kadencji parlamentu stosowana jest również w dominiach (m.in. w Australii, Kanadzie i Nowej Zelandii), gdzie rozwiązanie izby należy do kompetencji urzędującego gubernatora generalnego ${ }^{45}$.

W państwach Europy kontynentalnej, gdzie najczęściej przyjmowane są sztywne ramy kadencji parlamentu, rozwiązanie izby traktowane jest tradycyjnie jako wyjątkowa sytuacja. Podjęcie decyzji w tym zakresie uznawane jest wobec tego za prerogatywę głowy państwa i w konsekwencji nie stawia się nawet żadnych merytorycznych ograniczeń dla jej wykonywania. Widoczne jest to przede wszystkim w systemie konstytucyjnym V Republiki, gdzie prezydent może w każdej chwili rozwiązać Zgromadzenie Narodowe bez konieczności kontrasygnaty ze strony premiera ${ }^{46}$.

$\mathrm{Z}$ analizy treści współczesnych konstytucji wynika, że coraz więcej państw wprowadza ograniczenia czasowe w wykorzystywaniu instytucji skrócenia kadencji parlamentu. W Rosji nie można podjąć decyzji o rozwiązaniu Dumy Państwowej w ciągu roku od jej wybrania, na Ukrainie prezydent nie może rozwiązać parlamentu

43 Widoczne jest to głównie w systemie prezydenckim Stanów Zjednoczonych Ameryki, gdzie prezydent nie ma żadnych możliwości skrócenia kadencji parlamentu. Rozwiązanie parlamentu przez egzekutywę stanowi z kolei klasyczną instytucję parlamentarno-gabinetowego systemu rządów.

44 W ten sposób w Wielkiej Brytanii tylko w drodze proklamacji monarchy o rozwiązaniu Izby Gmin możliwe jest formalne zakończenie kadencji parlamentu.

45 Do podjęcia takiej decyzji przez gubernatora generalnego wymagany jest jednak w każdym wypadku formalny wniosek premiera. Por. S.Bożyk, Parlament a egzekutywa w systemie ustrojowym dominium (Australia, Kanada, Nowa Zelandia), (w:) Prawo, parlament i egzekutywa we współczesnych systemach rządów, pod red. S. Bożyka, Białystok 2009, s. 229 i nast.

46 Pewne ograniczenie proceduralne zawiera jednak art. 12 ust. 1 konstytucji, zgodnie z którym prezydent może zarządzić rozwiązanie Zgromadzenia Narodowego „po zasięgnięciu opinii premiera i przewodniczących izb” (Konstytucja Republiki Francuskiej, tłumaczenie i wstęp W. Skrzydło, Warszawa 2005, s. 38). 
w okresie roku od daty przeprowadzenia wyborów parlamentarnych oraz w okresie sześciu miesięcy pozostających do końca kadencji prezydenta, w Portugalii oraz we Włoszech wprowadzono zakaz rozwiązania parlamentu w ostatnich sześciu miesiącach kadencji prezydenta, w Austrii dopuszcza się możliwość tylko jednokrotnego rozwiązania parlamentu z tego samego powodu. Inną formą ograniczania możliwości skrócenia kadencji parlamentu jest dopuszczalność jego rozwiązania wyłącznie $\mathrm{w}$ tych sytuacjach, które zostały enumeratywnie wymienione w treści konstytucji. Uczyniła tak przede wszystkim ustawa zasadnicza RFN z 1949 r., która przewiduje możliwość rozwiązania Bundestagu przez prezydenta tylko $\mathrm{w}$ dwóch przypadkach: a) gdy Bundestag nie jest w stanie dokonać wyboru większościowego kanclerza (art. 63), b) gdy Bundestag odrzuci wniosek kanclerza o udzielenie mu wotum zaufania (art. 67) ${ }^{47}$. Podobne unormowania zawierają też inne konstytucje, m.in. belgijska, grecka oraz estońska. Do najczęściej wymienianych przez konstytucje powodów uzasadniających skrócenie kadencji parlamentu przez głowę państwa należy brak zdolności parlamentu do wyłonienia składu rządu oraz wyczerpanie wszystkich przewidzianych w tym celu czynności proceduralnych ${ }^{48}$.

Drugą, znacznie rzadziej przewidywaną formą skrócenia kadencji parlamentu jest znana niektórym systemom ustrojowym instytucja samorozwiązania izby na mocy ustawy bądź też uchwały podjętej przez sam parlament. Samorozwiązanie parlamentu przewidywane jest m.in. w konstytucji Republiki Austriackiej. Przepis art. 29 ust. 2 tej ustawy zasadniczej stanowi, że: "Przed upływem kadencji Rada Narodowa może w drodze ustawy zwykłej uchwalić swoje rozwiązanie"49. Prawo skrócenia kadencji parlamentu w drodze suwerennej decyzji samej izby przedstawicielskiej przewidziane jest również w Izraelu. Podjęcie decyzji w tym zakresie może nastapić na podstawie przepisu art. 34 Ustawy Zasadniczej o Knesecie ${ }^{50}$. W świetle tego przepisu konstytucyjnego Knesetowi przysługuje prawo samorozwiązania się przed upływem kadencji wyłącznie w drodze ustawy uchwalonej w tym celu bezwzględną większością głosów członków Knesetu ${ }^{51}$.

Konstytucje państw współczesnych nie przewidują z kolei możliwości przedłużania czasu trwania kadencji parlamentu, jeśli nie przemawiają za tym szczególne okoliczności. Jedynym wyjątkiem jest dopuszczalność przedłużania kadencji parlamentu i innych organów państwa w czasie obowiązywania stanów nadzwyczajnych. Przykładem tego może być chociażby praktyka ustrojowa Wielkiej Brytanii w okresach obu wojen światowych, kiedy konieczne było ustawowe wydłużenie ka-

\footnotetext{
47 Konstytucja Niemiec, wstęp B. Banaszak, Warszawa 2008, s. 63 i nast.

48 Por. B. Banaszak, Porównawcze prawo konstytucyjne..., s. 441.

49 Federalna Ustawa Konstytucyjna..., s. 69.

50 Konstytucja Państwa Izrael, tłumaczenie i wstęp K. Wojtyczek, Warszawa 2001, s. 52.

51 Dotychczas była to jedyna praktykowana w Izraelu forma skrócenia kadencji Knesetu. Por. S. Bożyk, System konstytucyjny Izraela, Warszawa 2002, s. 51.
} 
dencji Izby Gmin ${ }^{52}$. Przedłużenie kadencji parlamentu podczas obowiązywania stanów nadzwyczajnych przewiduje również obowiązująca Konstytucja RP z 2 kwietnia 1997 roku.

6. Zasada kadencyjności parlamentu, czyli wybierania go na okres, w ramach którego jest on władny realizować swoje konstytucyjne funkcje, przyjęta została także w polskiej ustawie zasadniczej ${ }^{53}$. Formułuje ją przepis art. 98 ust. 1 Konstytucji RP z 1997 r., który postanawia w tej kwestii, że "Sejm i Senat są wybierane na czteroletnie kadencje”. Określa on jednocześnie precyzyjnie ramy czasowe kadencji parlamentu, stwierdzając, iż: „Kadencje Sejmu i Senatu rozpoczynają się z dniem zebrania się Sejmu na pierwsze posiedzenie i trwają do dnia poprzedzającego dzień zebrania się Sejmu następnej kadencji”. Z treści art. 98 ust. 1 wynika więc, że kadencje obu izb parlamentu są ze sobą ściśle powiązane. W konsekwencji kadencja Senatu liczy się od dnia, w którym Sejm zebrał się na pierwsze posiedzenie po wyborach, mimo że pierwsze posiedzenie Senatu zwoływane jest zwykle na inny dzień. Także ostatni dzień kadencji Sejmu jest jednocześnie ostatnim dniem kadencji Senatu. Poza tym obecna ustawa zasadnicza nie przewiduje żadnej przerwy międzykadencyjnej, gdyż upływ „starej” kadencji parlamentu i początek ,nowej” zbiegają się w tym samym terminie ${ }^{54}$.

Ewentualne przedłużenie czteroletniej kadencji parlamentu byłoby dopuszczalne tylko w drodze zmiany treści art. 98 ust. 1 obowiązującej Konstytucji RP. Bez dokonywania zmiany ustawy zasadniczej kadencja parlamentu mogłaby zostać wydłużona wyłącznie w jednym przypadku, a mianowicie podczas obowiązywania jednego ze stanów nadzwyczajnych. Taka możliwość wynika bowiem z przepisu art. 228 ust. 7, który przewiduje, że w czasie stanu nadzwyczajnego oraz w ciagu 90 dni po jego zakończeniu nie mogą odbywać się wybory do Sejmu, Senatu, organów samorządu terytorialnego oraz wybory Prezydenta Rzeczypospolitej, a kadencje tych organów ulegają odpowiedniemu przedłużeniu ${ }^{55}$.

Przepisy Konstytucji RP przewidują natomiast skrócenie kadencji parlamentu. Jest ono dopuszczalne jedynie po spełnieniu szczególnych wymogów formalnych i może nastapić z zastosowaniem dwóch wariantów: a) w formie własnej decyzji parlamentu, 2) decyzją podjętą przez Prezydenta Rzeczypospolitej.

\footnotetext{
52 W okresie I wojny światowej kadencja Izby Gmin trwała 7 lat i 10 miesięcy, natomiast podczas II wojny światowej 9 lat i 7 miesięcy.

53 Por. S. Bożyk, Parlament Rzeczypospolitej Polskiej, (w:) Prawo konstytucyjne, pod red. M. Grzybowskiego, Białystok 2009, s. 221 i nast.

54 Por. A. Ławniczak, M. Masternak-Kubiak, Zasada kadencyjności Sejmu - wybrane problemy, „Przegląd Sejmowy" 2002, nr 3, s. 15 i nast.

55 Por. B. Banaszak, Konstytucja Rzeczypospolitej Polskiej. Komentarz, Warszawa 2009, s. 969 i nast.
} 
Podjęcie decyzji o skróceniu konstytucyjnie określonej kadencji przez sam parlament to tzw. samorozwiązanie. Przewiduje je art. 98 ust. 3 Konstytucji, który stanowi, że: "Sejm może skrócić swoją kadencję uchwałą podjętą większością co najmniej 2/3 głosów ustawowej liczby posłów". Oznacza to, iż do podjęcia decyzji Sejmu o samorozwiązaniu parlamentu wymaganych jest 307 głosów poselskich ${ }^{56}$. Następstwem podjęcia przez Sejm decyzji w sprawie samorozwiązania izby jest każdorazowo także zakończenie kadencji Senatu.

Gdy decyzję w sprawie przedterminowego upływu kadencji Sejmu podejmuje Prezydent RP, ma miejsce skrócenie kadencji obu izb parlamentu. Przewiduje je art. 98 ust. 4 Konstytucji, stwierdzając, że: "Prezydent Rzeczypospolitej, po zasięgnięciu opinii Marszałka Sejmu i Marszałka Senatu, może w przypadkach określonych w Konstytucji zarządzić skrócenie kadencji Sejmu. Wraz ze skróceniem kadencji Sejmu skrócona zostaje również kadencja Senatu". W obecnym stanie prawnym Prezydent RP ma możliwość podjęcia decyzji o skróceniu kadencji parlamentu jedynie w dwóch przypadkach, bardzo wyraźnie określonych w treści ustawy zasadniczej. Po pierwsze, gdy zostaną wyczerpane wszystkie przewidziane w Konstytucji możliwości powołania Rady Ministrów, a więc w przypadku odrzucenia przez Sejm po raz trzeci wniosku o wotum zaufania dla rządu - wówczas skrócenie kadencji jest obligatoryjne (art. 155 Konstytucji). Po drugie, jeżeli w ciagu 4 miesięcy od przedłożenia Sejmowi projektu ustawy budżetowej nie zostanie ona przedstawiona Prezydentowi RP do podpisu - wówczas skrócenie kadencji jest fakultatywne (art. 225 Konstytucji). 


\title{
PARLIAMENTARY TERM IN CONTEMPORARY CONSTITUTIONAL SYSTEMS
}

\author{
SUMMARY
}

The study presents the issue of the Parliamentary term as the time of its authority granted during elections. It provides the comparison of different legal solutions concerning that matter, particularly focusing on constitutional regulations legally binding in particular countries. The author analyses the duration of a parliamentary term, the rules for the calculation of the beginning and ending of the term of office as well as the possibilities of its shortening or prolonging. He also depicts various rules of counting the term of both houses of two-house parliaments. Moreover, different issues concerning the term of the Polish parliament were taken into account, with the focus on the corresponding effective legal provisions of the Constitution of the Republic of Poland of 2 April 1997. 